Gut, 1986, 27, 405-410

\title{
Human Peyer's patches: an immunohistochemical study
}

\author{
JO SPENCER, TERESA FINN, AND P G ISAACSON \\ From the Department of Histopathology, University College London School of Medicine, London
}

SUMmaRY We have used immunoperoxidase techniques to characterise the Peyer's patches in human terminal ileum. The mantle zones of the B cell follicles in human Peyer's patches were surrounded by B cells which did not express surface IgD but which mostly expressed surface immunoglobulin of the IgM and/or IgA1 isotype. Few cells expressing surface IgG or IgA2 were detected. Cells with cytoplasmic immunoglobulin of all isotypes except IgD were present in the dome regions of the Peyer's patches as well as in the lamina propria. There was little evidence of traffic of immunoglobulin synthesising cells across the high endothelial venules. T cells were seen to surround the lymphoid follicles. They were most concentrated on the serosal aspect around the high endothelial venules. Cells with macrophage-like morphology were present in both the lamina propria and the dome region of the follicles; those in the lamina propria containing lysozyme and those in the dome region $\mathrm{S} 100$ protein. The results are discussed in relation to the generation and dissemination of antibody producing cells in human gut.

A wealth of information is available which defines the processes involved in the activation, maturation and migration of $B$ cells resulting from immunological stimulation of the guts of laboratory animals. Some of the B cells activated in the Peyer's patches migrate to the mesenteric lymph nodes where they mature into antibody producing cells. ${ }^{1}$ These cells then enter the blood through the thoracic duct and localise in the lamina propria of the gut where they become plasma cells secreting antibody predominantly of the $\operatorname{IgA}$ isotype. ${ }^{2}{ }^{3}$ Sminia and Plesch ${ }^{4}$ have supported these observations in rats using immunohistochemistry.

It is tempting to apply these theories on the development of antibody producing cells in the gut directly to human tissue, but there are differences between the gut associated lymphoid tissue of man and laboratory animals even on a fundamental level. First, the Peyer's patches themselves are distributed differently. Peyer's patches in untreated human tissue are macroscopically invisible and they are distributed in small clusters throughout the gastrointestinal tract, being most concentrated in the terminal ileum. ${ }^{5}$ The Peyer's patches of mice and

Address for correspondence: Dr J M Spencer, Department of Histopathology, University College London School of Medicine, University Street, London. WC1E 6JJ.

Received for publication 21 June 1985. rats, however, are found in approximately 10 clusters along the length of the ileum ${ }^{6}$ and in sheep they are densely concentrated in the terminal ileum. ${ }^{7}$ In these species the Peyer's patches are clearly visible macroscopically on the serosal surface of the bowel. Secondly the synthesis of $\operatorname{IgA}$ in human tissue is not restricted to the mucosae to the extent seen in rats. Unlike rats which synthesise mostly dimeric IgA, man synthesises both monomeric and dimeric forms of two subclasses of $\operatorname{IgA}$, the monomeric form not apparently being involved in the protection of mucosal surfaces because of its inability to combine with secretory component. Because of these differences between the gut associated lymphoid tissue of laboratory animals and man we have made an immunohistochemical study of the Peyer's patches in human ileum the priority being to look for evidence of the maturation sites of antibody synthesising cells generated in the Peyer's patches and the migratory route of these B-cells to the lamina propria.

\section{Methods}

TISSUE COLLECTION AND PROCESSING

Terminal ileum was collected from seven right hemicolectomy specimens resected at laparotomy for adenoma or carcinoma of the colon. The patients 
were four women and three men ranging in age from 17-91 years. Specimens of macroscopically normal ileum were fixed in $10 \%$ formalin containing $2 \%$ acetic $\mathrm{acid}^{8}$ and routinely processed and embedded for paraffin sections. Tissue was also snap frozen in liquid nitrogen for frozen sections. Sections of terminal ileum were stained using haematoxylin and eosin. Blocks that contained Peyer's patch follicles were selected for immunohistochemistry.

\section{IMMUNOHISTOCHEMISTRY}

The sources and the specificities of the antibodies used throughout this study are shown in the Table.

Paraffin sections for immunostaining were dewaxed, rehydrated, and subjected to controlled trypsin digestion for optimal staining. " Frozen sections were air dried for half an hour and fixed in fresh acetone for half an hour immediately before staining.

With the polyclonal primary antibodies a peroxidase anti-peroxidase technique was used, and the monoclonal primary antibodies were used with a peroxidase conjugated secondary antibody. Peroxidase activity was shown using the 3,3-diaminobenzidine reagent. ${ }^{12}$ The precise details of the techniques have been published elsewhere. ${ }^{13}$

\section{Results}

MORPHOLOGICAL OBSERVATIONS

The most prominent feature of Peyer's patch follicles was the follicle centre which contained large

Table Antibodies used in this study

\begin{tabular}{|c|c|c|}
\hline $\begin{array}{l}\text { Monoclonal } \\
\text { antibodies }\end{array}$ & Source & Specificity \\
\hline$-\cdots$ & $\cdots-\cdots-\cdots$ & $-\ldots-\cdots--$ \\
\hline $\operatorname{IgD}$ & Coulter Clone & o-chains \\
\hline IgM & Coulter Clone & $\mu$-chains \\
\hline $\operatorname{IgA} \mid$ & Scward Laboratories & al-chains \\
\hline $\operatorname{IgA} 2$ & Scward Laboratorics & $\alpha 2$-chains \\
\hline $\mathrm{T} 1$ & $*$ & $\mathrm{~T}$ cclls \\
\hline $\mathrm{T} 4$ & * & Suppressor T cells \\
\hline Leu3a & Beckton Dickinson & Helper cells \\
\hline $\mathrm{Nal} / 34$ & Sera Lab & $\begin{array}{l}\text { Langerhans cells, } \\
\text { interdigitating cells } \\
\text { and cortical thymocytes }\end{array}$ \\
\hline KB61 (9) & $t$ & $\begin{array}{l}\text { B cells other than } \\
\text { follicle centre cells }\end{array}$ \\
\hline IB5 (10) & $\ddagger$ & HLA-D region antigen \\
\hline \multicolumn{3}{|c|}{ Polyclonal antisera } \\
\hline $\operatorname{lgG}$ & Dakopatts & $\gamma$-chain \\
\hline Lysozyme & Dakopatts & Lysozyme \\
\hline $\operatorname{Sin}(0)$ & Dakopatts & Cow $\mathrm{S} 100$ brain protein \\
\hline
\end{tabular}

Antisera were kindly provided by ${ }^{*}$ Drs $P$ Beverley and $\ddagger$ Dr T Adams of the Imperial Cancer Rescarch Fund, London. tDr K Pulford of the John Radeliffe Hospital, Oxford. centroblasts with euchromatic nuclei and medium sized centrocytes with irregularly shaped heterochromatic nuclei. The follicle centre was surrounded by a mantle with indistinct borders composed of small lymphocytes which merged into a mixed population of cells in the dome region of the follicle. In addition to some small lymphocytes, the dome region contained plasma cells, macrophages
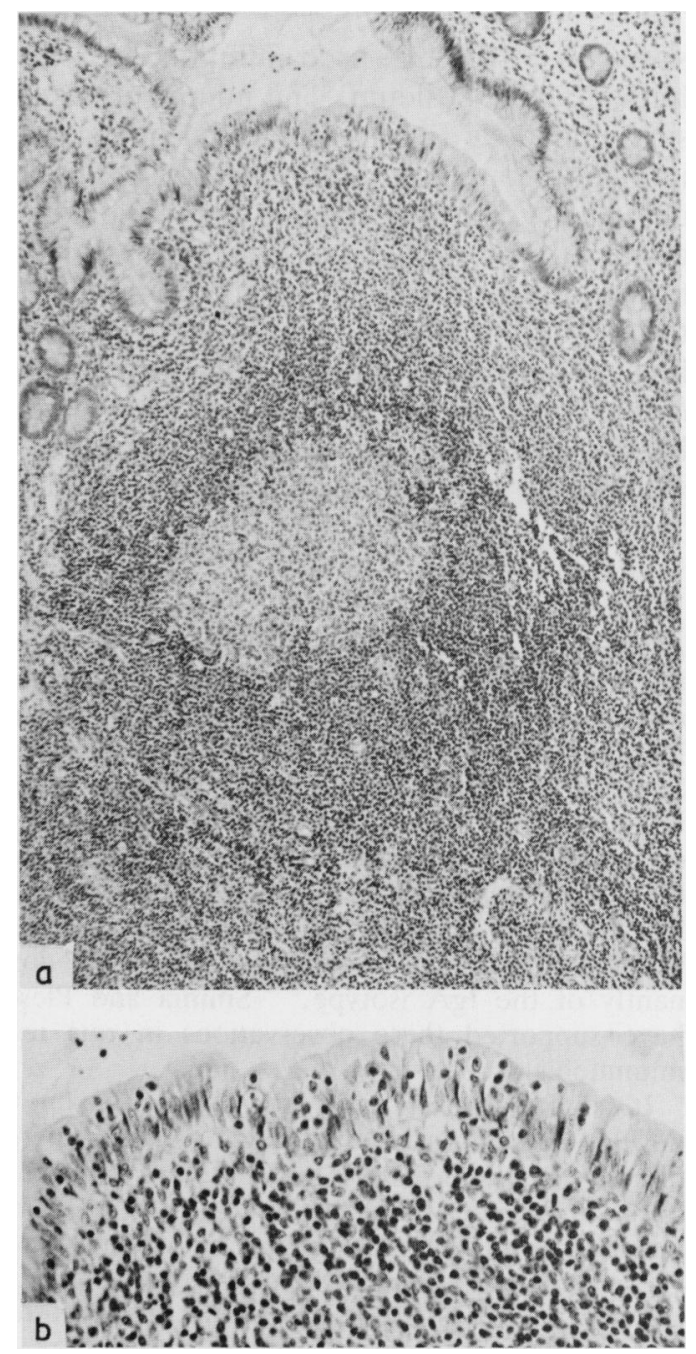

Fig. 1 Paraffin section of Peyer's patch from terminal ileum. (a) The follicle centre is surrounded by a mantle of small lymphocytes which has indistinct borders. The mantle zone merges with a population of cells of intermediate size and irregular nuclear outlines. These cells are illustrated in (b) where they extend from the dome region of the follicle into the overlying epithelium. Haematoxylin and eosin, (a) $\times 125$, (b) $\times 280$, orig mag. 

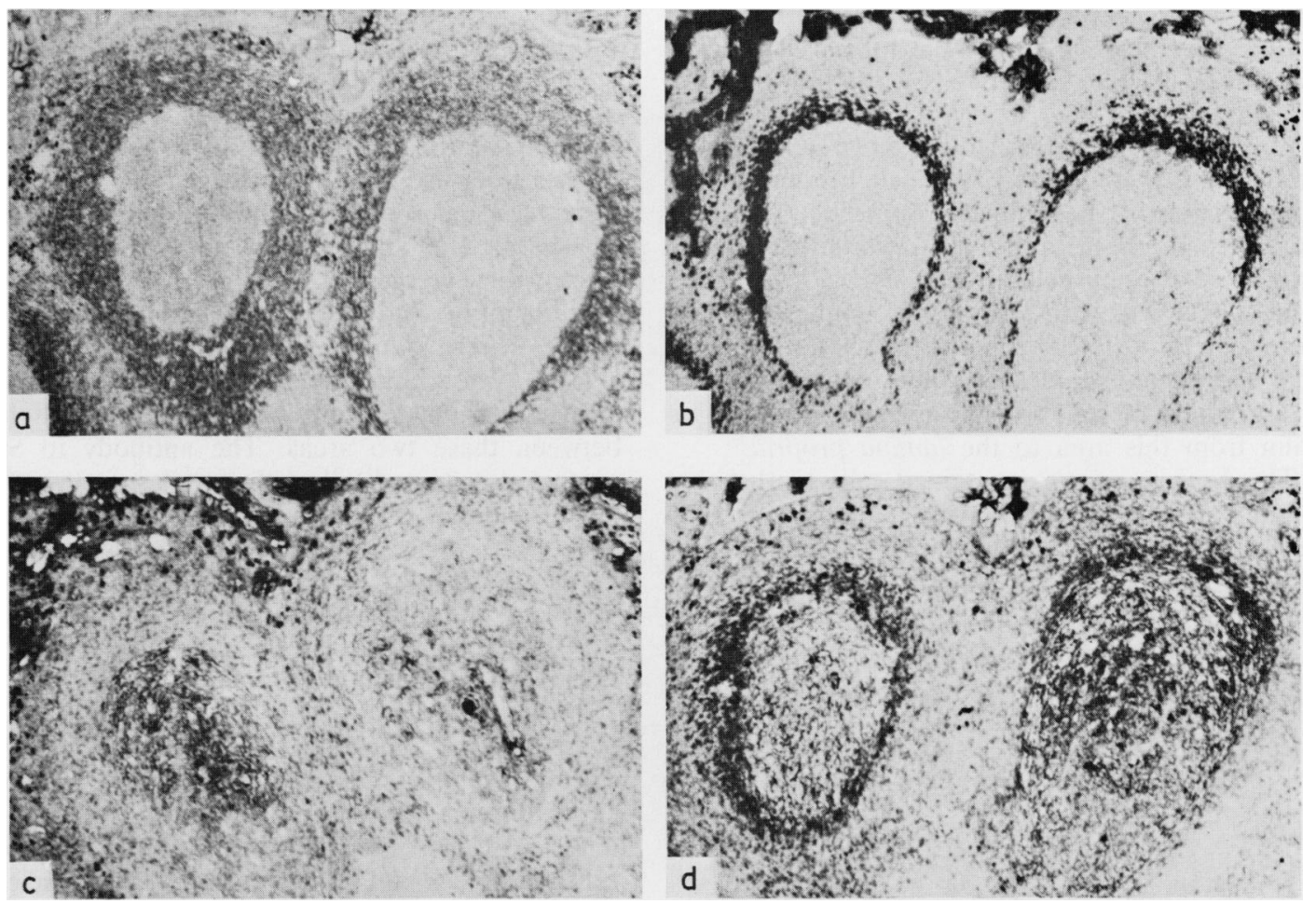

Fig. 2 Serial frozen sections of a Peyer's patch immunostained using (a) the monoclonal antibody KB6I which recognises an antigen on $B$ cells other than follicle centre $B$ cells, (b) anti-IgD, (c) anti-IgAI, (d) anti-IgM. B cells recognised by KB61 are present in excess of the mantle cells which express surface $\operatorname{Ig} D$. Most of the $B$ cells which surround the mantle zone appear to express sIgM and/or sIgA1. Immunoperoxidase $(\times 100$, orig. mag).

and cells with irregularly shaped heterochromatic nuclei similar to the centrocytes in the follicle centre (Fig. 1). These cells were also present infiltrating between the epithelial cells of the dome, but not the epithelium of the adjacent crypts. They were also continuous with the zone of cells on the serosal aspect of the follicle which contained the high endothelial venules.

\section{IMMUNOHISTOCHEMICAL OBSERVATIONS \\ Frozen sections}

Cells with surface immunoglobulin (sIg) were studied in cryostat sections of Peyer's patches. Clear rings of immunostaining were seen around the outside of cells with sIg rather than the thicker more diffuse rings of staining which surrounded the nuclei of cells with cytoplasmic immunoglobulin (cIg).

The mantle zone was composed of cells with sIgD and sIgM but this was diminuitive when compared with the total number of $B$ cells present in the Peyer's patches outside the follicle centre (Fig. 2 a,b). Cells with $\mathrm{sIgM}$ and $\operatorname{sIgA} 1$ surrounded the mantle zone extending both into the dome region and between the dome epithelial cells and into the T cell zone (Fig. 2 b,c,d). Cells with sIgA2 and sIgG could be seen occasionally in the Peyer's patches.

The follicle centres contained network staining of immunoglobulin of all isotypes except IgD. This immunoglobulin bound to the follicular dendritic reticulum cells masked any positivity which may have been present on the follicle centre cells themselves.

Helper and suppressor T-cells were present in the $\mathrm{T}$-cell zones extending around the follicles and into the mixed cell zones, the ratio of helpers to suppressors being approximately 7:1 but this varied between individuals. T helper cells were observed in the follicle centres.

The antibody $\mathrm{Nal} / 34$ recognised only occasional cells between the follicles in Peyer's patches. No cells were stained in the dome regions.

\section{Paraffin sections}

Most of the cells with clg were observed in the dome regions of the Peyer's patches and the adjacent 
lamina propria, although some cells with cIg could occasionally be seen within the follicle centres. It was not possible to detect cells with sIg in paraffin sections.

Cells with $\operatorname{cIg} \mathrm{A} 1, \operatorname{cIg} \mathrm{A} 2$, cIgM and $\operatorname{cIgG}$ (in order of decreasing frequency) were all present in the dome regions of the follicles. Some of these cells were clearly plasma cells. No cells with cIg were present in the epithelium (Fig. 3).

Very few cells with cytoplasmic immunoglobulin were seen in the T-cell zones in association with the high endothelial venules and there was no evidence of a gradient of cells with cytoplasmic immunoglobulin from this area to the lamina propria.

The lamina propria contained cells synthesising immunoglobulin of all isotypes, cells synthesising $\operatorname{IgA} 1$ and $\operatorname{IgA} 2$ being the most abundant. The

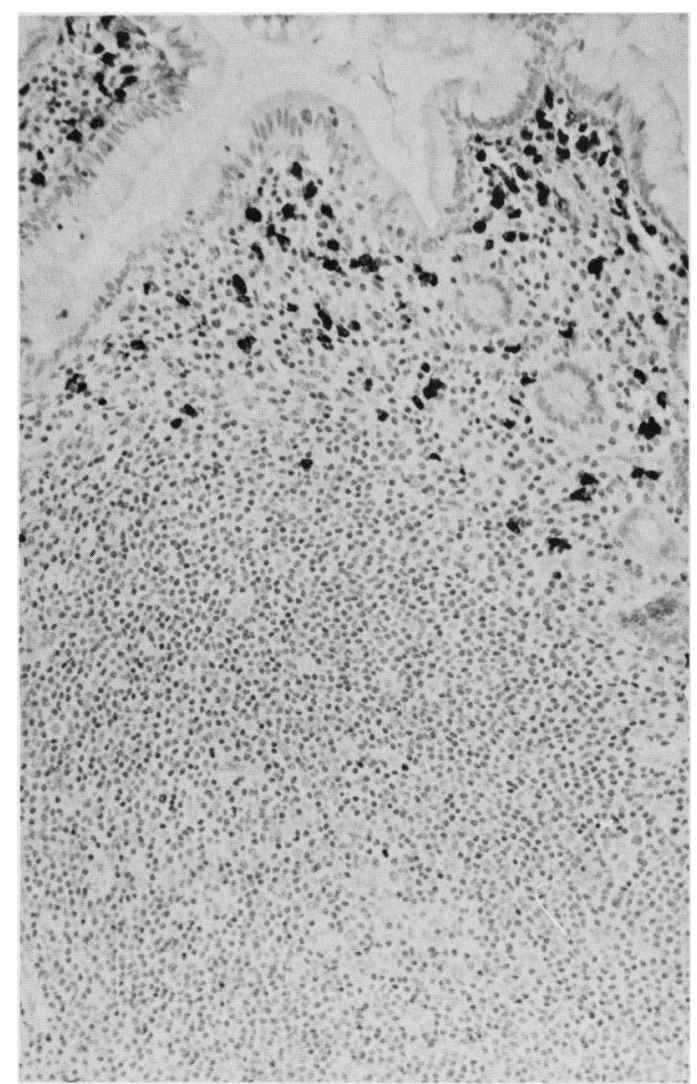

Fig. 3 Paraffin sections of Peyer's patches immunostained using anti-IgA1. Cells with cytoplasmic $\mathrm{IgAl}$ are present in the dome of the Peyer's patch and between the crypts but not in the dome epithelium. Immunoperoxidase $(\times 200$, orig. mag). frequency of cells with cIgG appeared to decrease with increasing distance from the follicle.

There were many cells in the Peyer's patches expressing HLA-DR antigens which extended into the dome epithelium. Some of these cells resembled the centrocytes in the follicle centres and others resembled macrophages, having long cytoplasmic processes. The antilysozyme antibody recognised cells with cytoplasmic processes in the lamina propria but it failed to stain cells in the dome regions of the Peyer's patch follicles with equal intensity (Fig. 4). There appeared to be a qualitative difference in staining of cells with similar morphology between these two areas. The antibody to S100 protein also stained cells with cytoplasmic processes but in contrast with the lysozyme containing cells these were concentrated in the dome regions of the Peyer's patch follicles, decreasing in frequency with increasing distance from the follicles (Fig. 4).

\section{Discussion}

Peyer's patch follicles as described in this report closely resemble the lymphoid follicles in human appendix with the exception of the $B$ cells in the dome regions of the follicles. The population of $B$ cells which lack sIgD which surround the follicles in the Peyer's patches is much less well represented in the appendix. In the appendix these cells can only be clearly identified when they show their characteristic tendency to infiltrate the dome epithelium. Unlike follicles in the appendix the dome regions of the Peyer's patch follicles contain cells with cytoplasmic Ig.

Antigen presentation is thought to occur in the dome regions of Peyer's patches and to involve cells with dendritic processes. ${ }^{14} 15$ Cells recognised by $\mathrm{Na} / 34$ and lysozyme were rarely seen in the dome. A population of cells with cytoplasmic processes which contained S100 protein was shown to have the distribution which would be expected of cells responsible for antigen presentation and they may be involved in this process. These cells may be analogous to the T6 and $\mathrm{C} 3 \mathrm{~b}$-receptor negative, HLA-DR positive cells described in skin and lymph node by Ralfkaier et al. ${ }^{16}$

The distribution of cells with sIg and cIg in human gut associated lymphoid tissue contrasts sharply with that observed in similar studies of animal tissue. Sminia and Plesch used immunohistochemistry to characterise the cells expressing $\mathrm{SIg}$ and $\mathrm{cIg}$ in the Peyer's patches of rats. ${ }^{4}$ These authors showed that although cells with sIg of all isotypes were present in the Peyer's patches of rats, only cells with cIgM and cIgG could be found in the dome regions of the follicles. Cells with cIgA were detected in the T-cell 

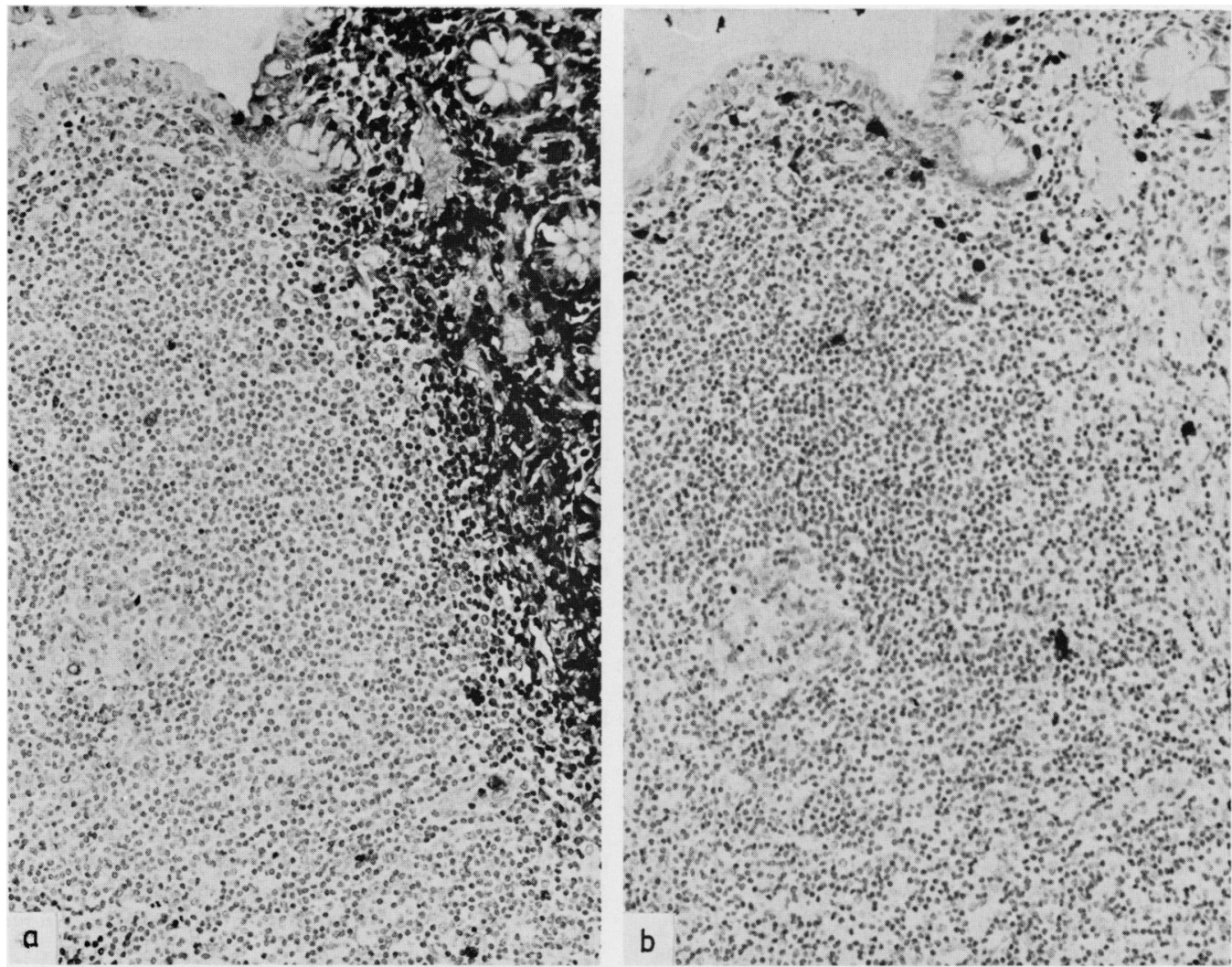

Fig. 4 Serial paraffin sections of a Peyer's patch immunostained using antisera to (a) lysozyme and (b) SIO0 protein. Lysozyme containing macrophages are present in abundance between the crypts (Lysozyme released from the macrophages results in generalised staining of this area), but not in the dome region. In contrast with this, cells with cytoplasmic processes containing $S 100$ protein are concentrated in the dome area. $(\times 200$, orig. mag $)$.

zones presumably extravasating into the gut associated lymphoid tissue. This supports experimental evidence that $\operatorname{Ig}$ A secreting $B$ cells activated in the Peyer's patches mature in the mesenteric lymph nodes, enter the blood via the thoracic duct and return to the gut through the high endothelial venules in the T cell zones of the Peyer's patches. The B cells in human Peyer's patches differ from those in rat Peyer's patches both in the isotypes of immunoglobulin that they express and also the distribution of cells with sIg and cIg. In human tissue only cells with $\operatorname{sIgM}$ and $\operatorname{sIgA} 1$ were clearly and consistently present in the Peyer's patches, cells expressing other isotypes were comparatively rare. Cells with cIg of all isotypes other than $\operatorname{IgD}$, however, could be observed in the dome regions of human Peyer's patches. The presence of cells with $\operatorname{cIg} \mathrm{A}$ in the dome regions of human Peyer's patches is of particular importance. In human, unlike rat tissue, cells fated to synthesise $\operatorname{IgA}$ in the lamina propria may mature in the dome regions of the Peyer's patches together with the cells synthesising other isotypes. ${ }^{4}$ The study of Crago et al, ${ }^{17}$ showed that although lymphoid tissue associated with human mucosae contained a higher proportion of cells synthesising both $\operatorname{IgA} 2$ and J-chain than lymphoid tissue elsewhere, mesenteric lymph nodes appeared to be no different to lymph nodes elsewhere in the body. This again suggests that in human tissue, cells synthesising $\operatorname{IgA}$ may mature in the mucosa rather than in the mesenteric nodes.

There is little evidence of traffic of immunoglobulin synthesising cells within the $T$ cell zones of human Peyer's patches. If the immunoglobulin synthesising cells generated in the Peyer's patches reach the lamina propria via the lymphatics and the blood as shown in laboratory animals they appear not to return to the gut via the high endothelial venules, but they may use an alternative route such as the capillary network. 
The results of this study provide grounds to doubt that $\mathrm{B}$ cells activated in normal human gut associated lymphoid tissue behave in the same way as those generated in that of laboratory animals. There is little evidence as yet from immunocytochemical studies of human gut associated lymphoid tissue that B cells migrate via the mesenteric lymph nodes, the thoracic duct lymph and the blood to reach the lamina propria. The Peyer's patches which are diffusely distributed in the human ileum may be able to seed the lamina propria with antibody producing cells directly.

This work was supported by MRC Grant G8222346 CA.

\section{References}

1 Phillips-Quagliata JM, Roux ME, Arny $\mathrm{M}$, et al. Migration and regulation of $B$ cells in the mucosal immune system. In: McGhee JR, Mestecky J, eds. The secretory immune system. Ann NY Acad Sci 1983; 409: 194-203.

2 Craig SW, Cebra JJ. Peyer's patches: an enriched source of precursors for $\operatorname{IgA}$-producing immunocytes in the rabbit. J Exp Med 1971; 134: 188-200.

3 Hall JG, Parry DM, Smith ME. The distribution and differentiation of lymph-borne immunoblasts after intravenous injection into syngeneic recipients. Cell Tissue Kinet 1972; 5: 269-81.

4 Sminia T, Plesch BEC. An immunohistochemical study of cells with surface and cytoplasmic immunoglobulins in situ in Peyer's patches and Lamina propria of rat small intestine. Virchows Arch /Cell Pathol] 1982; 40: 181-9.

5 Cornes JS. Number, size, and distribution of Peyer's patches in the human small intestine. Part 1. The development of Peyer's patches. Gut 1965; 6: 225-33.

6 Abe K, Ito T. A qualitative and quantitative morphologic study of Peyer's patches of the mouse. Arch Histol Jpn 1977; 40: 4()7-20.

7 Reynolds JD. Morris B. The effect of antigen on the development of Peyer's patches in sheep. Eur $J$ Immunol 1984; 14: 1-6.
8 Curran RC, Gregory J. Effects of fixation and processing on immunohistochemical demonstration of immunoglobulin in paraffin sections of tonsil and bone marrow. J Clin Pathol 1980; 33: 1047-57.

9 Pulford KAF, Ralfkaier E, MacDonald SM, Erber WN, Falini B, Gatter KC, Mason DY. A new monoclonal antibody (KB61) recognising an antigen of 40000 molecular weight which is selectively expressed on a subpopulation of human lymphocytes. Immunology (In press).

10 Epenetos AA, Bobrow LG, Adams TE, Collins CM, Isaacson PG, Bodmer WF. A monoclonal antibody that detects HLA-D region antigen in routinely fixed, wax embedded sections of normal and neoplastic lymphoid tissue. J Clin Pathol 1985; 38: 12-17.

11 Mepham BL, Frater W, Mitchell BS. The use of proteolytic enzymes to improve immunoglobulin staining by the PAP technique. Histochem J 1979; 11: 345-57.

12 Graham RC, Karnovksy MJ. The early stages of absorption of injected horseradish peroxidase in the proximal tubules of the mouse kidney. Ultrastructural cytochemistry by a new technique. J Histochem Cytochem 1966; 14: 291-302.

13 Isaacson $\mathrm{P}$, Wright $\mathrm{DH}$. Immunocytochemistry of lymphoreticular tumours. In: Polak JM, Van Noorden $\mathrm{S}$, eds. Immunocytochemistry. Practical applications in pathology and biology. Bristol: John Wright, 1983: 249-73.

14 Unanue ER. The regulatory role of macrophages in antigenic stimulation. Part two: symbiotic relationship between lymphocytes and macrophages. Adv Immunol 1981; 31: 1-136.

15 Richman LK, Graeft AS, Strober W. Antigen presentation by macrophage enriched cells from the mouse Peyer's patch. Cell Immunol 1981; 62: 110-8.

16 Ralfkaier E, Stein H, Plesner T, Hou-Jensen K, Mason D. In situ immunological characterisation of Langerhans cells with monoclonal antibodies: comparison with other dendritic cells in skin and lymph nodes. Virchows Arch [Pathol Anat] 1984; 403: 401-12.

17 Crago SS, Kutteh WH, Moro I, Allansmith MR, Radl J, Haaijman JJ, Mestecky J. Distribution of $\operatorname{IgA1}$-, $\operatorname{IgA} 2-$, and $\mathrm{J}$ chain-containing cells in human tissues. $J$ Immunol 1984; 132: 16-18. 